\title{
An Economic Analysis of Incorporating Biomass Thinning into Loblolly Pine Plantations in Alabama
}

\author{
Tom V. Gallagher, Rapeepan Kantavichai, Larry D. Teeter \\ School of Forestry \& Wildlife Sciences, Auburn University, Auburn, USA \\ Email: kantavichai@outlook.com
}

How to cite this paper: Gallagher, T. V., Kantavichai, R., \& Teeter, L. D. (2017). An Economic Analysis of Incorporating Biomass Thinning into Loblolly Pine Plantations in Alabama. Open Journal of Forestry, 7, 172-187.

https://doi.org/10.4236/ojf.2017.72011

Received: February 3, 2017

Accepted: April 10, 2017

Published: April 13, 2017

Copyright (c) 2017 by authors and Scientific Research Publishing Inc. This work is licensed under the Creative Commons Attribution International License (CC BY 4.0).

http://creativecommons.org/licenses/by/4.0/

\begin{abstract}
The objective of this study was to perform breakeven analysis of a stumpage biomass price that would induce landowners to modify their management regimes to incorporate an early thinning for biomass products. Following the biomass thinning, traditional harvest of pulpwood and timber products would be conducted. The feasibility analysis of incorporating biomass thinning as a potential product for a biomass market was examined for Piedmont and Coastal Plain site scenarios in Alabama. We compared our proposed biomass thinning regime with a traditional management regime. In the Piedmont site scenario, the minimum biomass breakeven prices were lower than current pulpwood prices ranging from $\$ 4.75$ to $\$ 7.87 /$ ton depending on the discount rates applied (5\%,7\%, and $9 \%)$. However, the minimum breakeven prices were higher than pulpwood prices at all discount rates for the Coastal Plain site scenario. A benefit of early thinning improved sawtimber proportion in the final harvest of products based on PTEADA 4.0 simulations. Increases in sawtimber prices allow for lower biomass breakeven prices. Minimum biomass breakeven prices decreased by $13 \%, 30 \%$ and $70 \%$ when timber price increases were $20 \%, 50 \%$ and $100 \%$, respectively, under a $7 \%$ discount rate for the Piedmont site scenario.
\end{abstract}

\section{Keywords}

Biomass, Pre-Commercial Thinning, Stumpage Price, Nonindustrial Private Forests

\section{Introduction}

The development of cellulosic ethanol markets will contribute to the use of small diameter, understory trees and harvesting residues in loblolly pine (Pinus taeda) 
plantations in the South (Perlack \& Stokes, 2011, Rummer et al., 2012), leading to a higher level of silvicultural activities in young forest stands in terms of additional thinning and final harvests. Paula et al. (2011) conducted a survey in Lee County, Alabama (AL) and found that there is a relatively high willingness (84\%) among existing family forest landowners to supply biomass and timber harvest residues to support development of a biofuels industry. The most important factor influencing their decision is the biomass stumpage price. One third of the landowners in that study desired a price for biomass equal to pulpwood price, but more than one-third of landowners were unsure about their fair price calculation.

Several studies on the economics of planting short rotation loblolly pine for biomass have been conducted in Southeast forests. Munsell \& Fox (2010) compared the land expectation values (LEVs) in a simulated Coastal Plain situation and demonstrated that short rotation plantations for biomass are not viable under 2010 pulpwood prices. In Alabama, a biomass stumpage price that could encourage landowners to invest in short rotation plantations was determined to be approximately $\$ 10.50 /$ ton in the Piedmont (Kantavichai et al. 2014), which is more than the current pulpwood price. Achieving those levels would likely require harvesting system improvements as well as tax and other incentives for short rotation biomass plantations to be economically viable.

As alternatives to dedicated plantations, wood residuals from traditional harvests and noncommercial stems from early thinnings can be considered biomass source materials. Many forest landowners are willing to supply wood residues and pre-commercial thinning products for biomass as long as their value covers harvesting costs (Paula et al., 2011). An important gap in existing literature is establishing the feasibility of alternative management regimes for biomass that include thinning. Biomass thinning has a potential to provide a promising feedstock from the fact that it has been shown to be economically feasible on a national scale (Rummer et al., 2003, Kocoloski et al., 2011) and in the Western forests (LeVan-Green and Livingston, 2001, Polagye et al., 2007). With most supplies from forest thinning projected to be concentrated in the Southeastern states, it is important that the feasibility analysis of thinning for biomass in the Southeast be evaluated.

Thinning of forest stands has been commonly acknowledged as the primary treatment for manipulating growth of loblolly pine (Bower, 1965, Cain \& Shelton, 2003, Cregg et al., 1988). By reducing competition between trees within a stand, thinning provides each tree of the residual stand with access to more light, soil nutrients and water, and growing space. Trees will increase their foliage mass over time leading to more crown and stem growth, especially in the stem base, meeting timber product specifications earlier and leading to a shorter rotation age. Thinning in young stands (less than 12 years old) is generally considered a pre-commercial treatment and is commonly applied as a heavy thinning from below in a dense or naturally regenerated stand. Due to the relatively high cost of pre-commercial thinning, this treatment has not been practiced very fre- 
quently in the past decade (Barlow \& Dubois, 2011). A common silviculture regime for loblolly pine plantations in the Southeast during this period included planting at a density of about 545 trees/ac (tpa) and thinning between 13 and 16 years of age producing trees that were large enough for pulpwood products (Gorman, 2012). With good prospects for a developing bioenergy market, thinning operations that formerly required a significant investment may have some more immediate economic benefit. Dense stands from either natural regeneration or planting may be candidates for an economical biomass thinning.

Studies showed that AL forest landowners have a high willingness to manage their land for biomass (Paula et al., 2011, Young et al., 2015). However, economic study of small tree thinning for biomass management has been rarely conducted. The objective of this study is to perform breakeven analysis of a stumpage biomass price that would induce landowners to modify their management regimes to incorporate an early thinning for biomass products followed by the harvest of traditional pulpwood and timber products from later thinning and final harvest on 2 typical AL sites located in the Piedmont and Coastal Plain. This study also conducts a sensitivity analysis of breakeven price when timber prices increase.

\section{Methods}

This study looked at two management scenarios: a traditional management regime (TMR) used as a benchmark and a biomass thinning regime (BTR). The objective was to find breakeven prices for biomass that would yield identical economic returns for the BTR and TMR, providing landowners with a viable option to traditional management that also contributes to biomass feedstock. One was located in the Piedmont plateau region and the other in the Coastal Plain of Alabama. Growth and yield for the BTR and TMR were simulated using the PTAEDA 4.0 growth model (Burkhart et al., 2008), which has been shown to produce reliable results for both young stands (Kantavichai et al., 2014) and rotation age stands (South et al., 2011).

\subsection{Site Description and Traditional Management Regime}

The Piedmont site productivity was assumed to be moderate (site index $65_{25}$ ) and the Coastal Plain site productivity was assumed to be high (site index $85_{25}$ ) at base age 25 years. The model simulated growth on "well-drained" sites using the "chop and burn" option to represent chemical site preparation for both sites and included "bedding" site preparation for the Coastal Plain site.

In the TMR, the Piedmont stand was established by planting $605 \mathrm{tpa}(8 \mathrm{ft} \times 9$ $\mathrm{ft}$ spacing) following with chemical site preparation and was thinned once at age 15 years old to $60 \mathrm{ft}^{2}$ basal area (BA) (Gorman, 2012). The final harvest year was determined based on a criterion of maximizing LEV given one of three real discount rates $(5 \%, 7 \%, 9 \%)$ and a set of real product prices (Table 1) obtained from Timber Mart-South (2012). Yearly average prices in North AL were used for the Piedmont site while yearly average prices in South AL were used for the Coastal Plain site. 
Table 1. Specification and real stumpage prices for traditional mixed products (Timber Mart-South, 2012).

\begin{tabular}{ccccc}
\hline & Unit & Pulpwood & Chip and Saw & Sawtimber \\
\hline Top diameter & in & 4 & 6 & 8 \\
dbh & in & 5 & 8 & 12 \\
Price for Piedmont site & \$/ton & 7.96 & 14.65 & 23.97 \\
Price for Coastal Plain site & \$/ton & 10.87 & 17.05 & 27.26 \\
\hline
\end{tabular}

Table 2. Traditional Management Regime Land Expected Values (LEV) and rotation ages in Piedmont site (site index $65_{25} ; 605$ tpa) and Coastal Plain site (site index $85_{25} ; 495$ tpa) at 3 discount rates $(5 \%, 7 \%, 9 \%)$.

\begin{tabular}{ccccc}
\hline \multirow{2}{*}{ Discount rate } & \multicolumn{2}{c}{ Piedmont site } & \multicolumn{2}{c}{ Coastal Plain site } \\
\cline { 2 - 5 } & LEV $(\$ /$ ac $)$ & Rotation age (years) & LEV $(\$ / a c)$ & Rotation age (years) \\
\hline $5 \%$ & 461 & 32 & 866 & 24 \\
$7 \%$ & 174 & 30 & 349 & 22 \\
$9 \%$ & 49 & 21 & 91 & 22 \\
\hline
\end{tabular}

The Coastal Plain site scenario was assumed to have a medium level of management intensity in the TMR. The stand was planted at $495 \mathrm{tpa}(8 \mathrm{ft} \times 11 \mathrm{ft}$ spacing) following chemical site preparation and bedding. A first thinning was simulated after 12 growing seasons leaving a residual BA of $60 \mathrm{ft}^{2}$. The thinning was followed by fertilizing with $25 \mathrm{P}+200 \mathrm{~N}$ lbs/ac. The final harvest was conducted between 5 - 10 years after thinning depending on which year produced the maximum LEV. Table 2 showed the highest LEVs and their rotation ages for the 2 sites (Piedmont and Coastal Plain), with 3 discount rates.

Examples of the TMR LEV calculation and associated cashflows are shown in Table 3 and Table 4 using the 2012 price (Timber Mart-South, 2012) and the real costs adjusted for inflation to fourth quarter 2012 (based on Barlow and Dubois, 2011, Guo et al., 2010, Dickens et al., 2005, and Plum Creek, 2010 (sited in Nepal 2012)). Net future value (NFV) was derived from the cost multiplying with compounding factors.

Piedmont LEV of TMR at 7\% discount rate was $\$ 174$ calculating from NFV for a 30 year rotation age.

$$
L E V_{\text {TRM }, \text { Piedmont }}=\frac{N F V_{\text {TRM }, \text { Piedmont }}}{1.07^{30}-1}=\frac{1151}{6.612}=174
$$

Coastal LEV of TMR was $\$ 349$ by using the same calculation method as in Piedmont.

$$
L E V_{\text {TRM }, \text { Coastal }}=\frac{N F V_{\text {TRM, Coastal }}}{1.07^{22}-1}=\frac{1198}{3.43}=349
$$

\subsection{Biomass Thinning Regime}

The biomass thinning regime assumed that the stand was planted at a high density and first thinned for biomass (biomass thinning), followed by a second 
T. V. Gallagher et al.

Table 3. Cash flow activities and Net Future values (NFV) at rotation age for traditional management regime in Piedmont site scenario at $7 \%$ discount rate.

\begin{tabular}{|c|c|c|c|c|c|}
\hline Year & Item & Amount (\$/ac) & Reference & Compounding factor & $\mathrm{NFV}(\$ / \mathrm{ac})$ \\
\hline 0 & Seedling & -73.21 & Plum creek 2012 & $1.07^{30}$ & -557 \\
\hline 0 & Chemical site preparation & -67.51 & Barlow and Dubois, 2011 & $1.07^{30}$ & -514 \\
\hline 15 & Pulpwood thinning & 218.04 & Timber Mart-South, 2012 & $1.07^{15}$ & 602 \\
\hline 30 & Harvest & 1820.13 & Timber Mart-South, 2012 & $1.07^{0}$ & 1820 \\
\hline \multirow[t]{2}{*}{$1-30$} & Administration cost & -2.11 & Guo et al., 2010 & $\frac{1.07^{30}-1}{0.07}$ & -199 \\
\hline & & & $N F V_{T M R, \text { Piedmont }}$ & & $\underline{1151}$ \\
\hline
\end{tabular}

Table 4. Cash flow activities and Net Future Values (NFV) at rotation age for traditional management regime in Coastal Plain site scenario at $7 \%$ discount rate.

\begin{tabular}{|c|c|c|c|c|c|}
\hline Year & Item & Amount (\$/ac) & Reference & Compounding factor & NFV $(\$ / a c)$ \\
\hline 0 & Seedling & -60.02 & Plum creek 2012 & $1.07^{22}$ & -266 \\
\hline 0 & Chemical site preparation & -67.51 & Barlow and Dubois, 2011 & $1.07^{22}$ & -299 \\
\hline 0 & Bedding & -216.95 & Barlow and Dubois, 2011 & $1.07^{22}$ & -961 \\
\hline 12 & Pulpwood thinning & 381.7 & Timber Mart-South, 2012 & $1.07^{10}$ & 751 \\
\hline 12 & Fertilization & -96.33 & Dickens et al., 2005 & $1.07^{10}$ & -189 \\
\hline 22 & Harvest & 2266.60 & Timber Mart-South, 2012 & $1.07^{0}$ & 2267 \\
\hline \multirow[t]{2}{*}{$1-22$} & \multirow[t]{2}{*}{ Administration cost } & \multirow[t]{2}{*}{-2.11} & Guo et al., 2010 & $\frac{1.07^{22}-1}{0.07}$ & -103 \\
\hline & & & $N F V_{T M R, \text { Coastal }}$ & & $\underline{1198}$ \\
\hline
\end{tabular}

thinning for traditional products (pulpwood thinning) and then final harvest. According to our criteria, the biomass thinning should occur early, between the ages 6 to 12. We also assumed that to be viable from a harvesting operator perspective, a biomass thinning must generate a minimum of 15 ton/ac of extracted biomass. The stand should be maintained at a basal area below $135 \mathrm{ft}^{2}$ in order to prevent stagnation and insect infestations. PTAEDA4.0 only gives stem biomass weight. We assumed aboveground biomass allocates 83 percent to the stem and 17 percent to dead branches, live branches and leaves based on recent biomass partition studies on dense young stands in Alabama and Georgia (Zhao et al., 2012). We also assumed a 10\% loss from the harvesting operation combined with this aboveground biomass ratio. The multiplication factor to get thinning biomass is $(0.83 / 0.9)=1.08$ used in converting stem biomass reported by the PTAEDA 4.0 simulations to aboveground biomass from thinning.

The Piedmont site was assumed to be planted in typically dense spacing on a 6 $\mathrm{ft} \times 8 \mathrm{ft}$ spacing (908 tpa) following a chemical site preparation treatment and follow-up herbaceous weed control treatment during the first year. The biomass thinning was a combination 3rd row and low thin to BA $60 \mathrm{ft}^{2}$ at an age in the range 9 - 12 years old (Table 5) and can be pulpwood low thinned to BA $60 \mathrm{ft}^{2}$ at $5,7,9,11$, or 13 years after the biomass thin and final harvested between 5 - 
Table 5. Stand characteristics and biomass quantities at possible biomass thinning ages for Piedmont site scenario (Bold rows were the excluded thinning ages due to failing basal area or harvested biomass criteria in italic).

\begin{tabular}{ccccccc}
\hline Year & Basal area, $\mathrm{ft}^{2}$ & Avg dbh, in & Avg height, $\mathrm{ft}$ & $\begin{array}{c}\text { \# thinned } \\
\text { trees }\end{array}$ & $\begin{array}{c}\text { Stem biomass, } \\
\text { ton }\end{array}$ & $\begin{array}{c}\text { Harvested } \\
\text { biomass, ton }\end{array}$ \\
\hline $\mathbf{7}$ & $\mathbf{8 3}$ & $\mathbf{4 . 3}$ & $\mathbf{2 2 . 6}$ & $\mathbf{2 3 9}$ & $\mathbf{8 . 6}$ & $\mathbf{9 . 2 9}$ \\
$\mathbf{8}$ & $\mathbf{9 4}$ & $\mathbf{4 . 5 8}$ & $\mathbf{2 4 . 8}$ & $\mathbf{3 2 4}$ & $\mathbf{1 1}$ & $\mathbf{1 1 . 8 8}$ \\
9 & 104 & 4.82 & 27 & 416 & 14.8 & 15.98 \\
10 & 113 & 5.03 & 28.9 & 462 & 19.1 & 20.63 \\
11 & 121 & 5.21 & 30.8 & 493 & 23.3 & 25.16 \\
12 & 129 & 5.38 & 32.6 & 519 & 28 & 30.24 \\
$\mathbf{1 3}$ & $\mathbf{1 3 6}$ & $\mathbf{5 . 7 3}$ & $\mathbf{3 6 . 4}$ & 531 & 32.9 & 35.53 \\
\hline
\end{tabular}

15 years after the pulpwood thinning.

On the Coastal Plain site, we assumed wider row spacing at planting $(5 \mathrm{ft} \times 10$ $\mathrm{ft}, 871 \mathrm{tpa}$ ) to accommodate the use of site preparation machines. Bedding was applied in this scenario for drainage improvement following chemical site preparation. Herbaceous weed control treatment was applied in the first growing season. Based on Table 6, biomass thinnable ages are from 6 to 9 years (3rd row and low thin to BA $60 \mathrm{ft}^{2}$ ) followed by fertilizing with $25 \mathrm{P}+200 \mathrm{~N}$ lbs/ac. Pulpwood low thins to BA $60 \mathrm{ft}^{2}$ followed by fertilizing with $25 \mathrm{P}+200 \mathrm{~N}$ lbs/ac were evaluated at $57,9,11$, and 13 years after the biomass thins. Similar to the Piedmont, final harvest ranges were evaluated for 5 to 15 years after the pulpwood thinning.

\section{Biomass Breakeven Price Calculation}

It was assumed that forest landowners would manage their forests in a way that would maximize the net present value of the cash flows by managing for biomass and timber. The breakeven (BEP) stumpage prices for the plantation with biomass thinning were the prices that allow the new regime to have the same LEV as the TMR LEV in Table 2.

For example, for the Piedmont scenario, LEV of TMR at a 7\% discount rate was $\$ 174.14$. That LEV can be matched with a BTR where the BEP is $\$ 5.72 /$ ton with 25 tons of biomass harvested at 11 years old (Table 5) and generating a cash flow of $\$ 144$ (Table 7). This calculation is demonstrated in regime 11_20_27 which means the stand was biomass thinned at 11 years old and then pulpwood thinned at 20 years old with a final harvest at 27 years old.

For the Coastal Plain site, the biomass BEP at 7\% was estimated to be $\$ 15.05$ and associated with a biomass harvest of 38.45 tons (Table 6) at 9 years old generating a cash flow of $\$ 578.64$ (Table 8) under regime 9_16_25 to achieve a LEV of $\$ 349$, same as the TMR LEV at $7 \%$.

$$
L E V_{\text {BTR,Coastal }}=\frac{N F V_{\text {BTR,Coastal }}}{1.07^{25}-1}=\frac{1547}{4.43}=349
$$


Table 6. Stand characteristics and biomass quantities at possible biomass thinning ages for Coastal Plain site scenario (Bold rows were the excluded thinning ages due to failing basal area or harvested biomass criteria in italic).

\begin{tabular}{ccccccc}
\hline Year & Basal area, $\mathrm{ft}^{2}$ & Avg dbh, in & Avg height, $\mathrm{ft}$ & \# thinned trees & Stem biomass, ton & Harvested biomass, ton \\
\hline $\mathbf{5}$ & $\mathbf{7 4}$ & $\mathbf{4 . 0 9}$ & $\mathbf{2 4 . 2}$ & $\mathbf{2 4 9}$ & $\mathbf{8}$ & $\mathbf{8 . 6 4}$ \\
$\mathbf{6}$ & 98 & 4.72 & 29.2 & 356 & 14.2 & 15.34 \\
7 & 114 & 5.09 & 33 & 442 & 22.4 & 29.19 \\
8 & 126 & 5.35 & 35.7 & 483 & 35.6 & 31.97 \\
9 & 135 & 5.54 & 37.7 & 506 & $\mathbf{4 0 . 5}$ & 38.45 \\
$\mathbf{1 0}$ & $\mathbf{1 4 2}$ & $\mathbf{5 . 6 9}$ & $\mathbf{5 7 . 5}$ & $\mathbf{5 1 9}$ & $\mathbf{4 3 . 7 4}$ \\
\hline
\end{tabular}

Table 7. Cash flow activities and Net Future Values at rotation age for biomass thinning regime 11-20-27 in Piedmont site scenario at $7 \%$ discount rate.

\begin{tabular}{|c|c|c|c|c|c|}
\hline Year & Item & Amount (\$/ac) & Reference & Compounding factor & $\operatorname{NFV}(\$ / a c)$ \\
\hline 0 & Seedling & -109.87 & Plum creek 2012 & $1.07^{27}$ & -683 \\
\hline 0 & Chemical site preparation & -67.51 & Barlow and Dubois, 2011 & $1.07^{27}$ & -419 \\
\hline 1 & Herbaceous weed control & -34.94 & Barlow and Dubois, 2011 & $1.07^{26}$ & -203 \\
\hline 11 & Biomass thinning & 143.94 & & $1.07^{16}$ & 425 \\
\hline 20 & Pulpwood thinning & 373.42 & Timber Mart-South, 2012 & $1.07^{7}$ & 600 \\
\hline 27 & Harvest & 1345.76 & Timber Mart-South, 2012 & $1.07^{0}$ & 1346 \\
\hline \multirow[t]{2}{*}{$1-27$} & Administration cost & -2.11 & Guo et al., 2010 & $\frac{1.07^{27}-1}{0.07}$ & -157 \\
\hline & & & $N F V_{B T R, \text { Piedmont }}$ & & $\underline{908}$ \\
\hline
\end{tabular}

Table 8. Cash flow activities and Net Future Values at rotation age for biomass thinning regime 9_16_25 in Coastal Plain site scenario at $7 \%$ discount rate.

\begin{tabular}{|c|c|c|c|c|c|}
\hline Year & Item & Amount (\$/ac) & Reference & Compounding factor & $\operatorname{NFV}(\$ / a c)$ \\
\hline 0 & Seedling & -105.51 & Plum creek 2012 & $1.07^{25}$ & -573 \\
\hline 0 & Chemical site preparation & -67.51 & Barlow and Dubois, 2011 & $1.07^{25}$ & -366 \\
\hline 0 & Bedding & -216.95 & Barlow and Dubois, 2011 & $1.07^{25}$ & -1177 \\
\hline 1 & Herbaceous weed control & -34.94 & Barlow and Dubois, 2011 & $1.07^{24}$ & -177 \\
\hline 9 & Biomass thinning & 578.64 & & $1.07^{16}$ & 1708 \\
\hline 9 & Fertilization & -96.33 & Dickens et al., 2005 & $1.07^{16}$ & -284 \\
\hline 16 & Pulpwood thinning & 384.31 & Timber Mart-South, 2012 & $1.07^{9}$ & 707 \\
\hline 16 & Fertilization & -96.33 & Dickens et al., 2005 & $1.07^{9}$ & -177 \\
\hline 25 & Harvest & 2020.33 & Timber Mart South, 2012 & $1.07^{0}$ & 2020 \\
\hline \multirow[t]{2}{*}{$1-25$} & Administration cost & -2.11 & Guo et al., 2010 & $\frac{1.07^{25}-1}{0.07}$ & -133 \\
\hline & & & $N F V_{B T R, \text { Coastal }}$ & & $\underline{1547}$ \\
\hline
\end{tabular}

\section{Results}

\subsection{Biomass Breakeven Price on a Piedmont Site}

At a given discount rate and for each biomass thinning age considered a partic- 
ular second thinning (primarily for pulpwood) and final harvest regime is associated with the lowest BEP. Feasible biomass thinning ages (based on threshold biomass harvest quantities) for the Piedmont site were determined to be 9, 10, 11, and 12 years old. Figures 1-3 show the biomass BEPs and final rotation ages for each biomass thinning age for three discount rates. The second (pulpwood) thinning age that combines with the final rotation age to yield minimum BEP is indicated as part of the label for each curve, for example, regime 9_20 represents biomass thinning at 9 years old and pulpwood thinning at 20 years old. It was

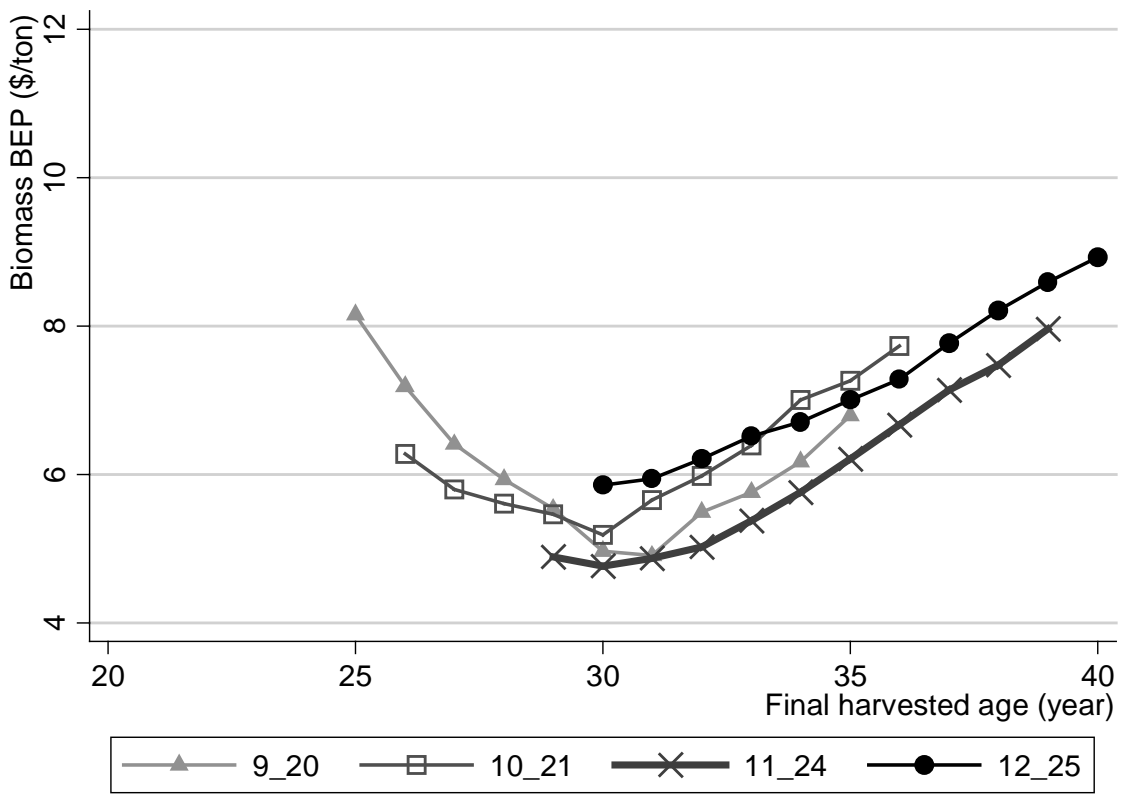

Figure 1. Breakeven price (BEP) curves and final rotation ages for biomass thinning ages from 9 to 12 years old on a Piedmont site at a $5 \%$ real discount rate.

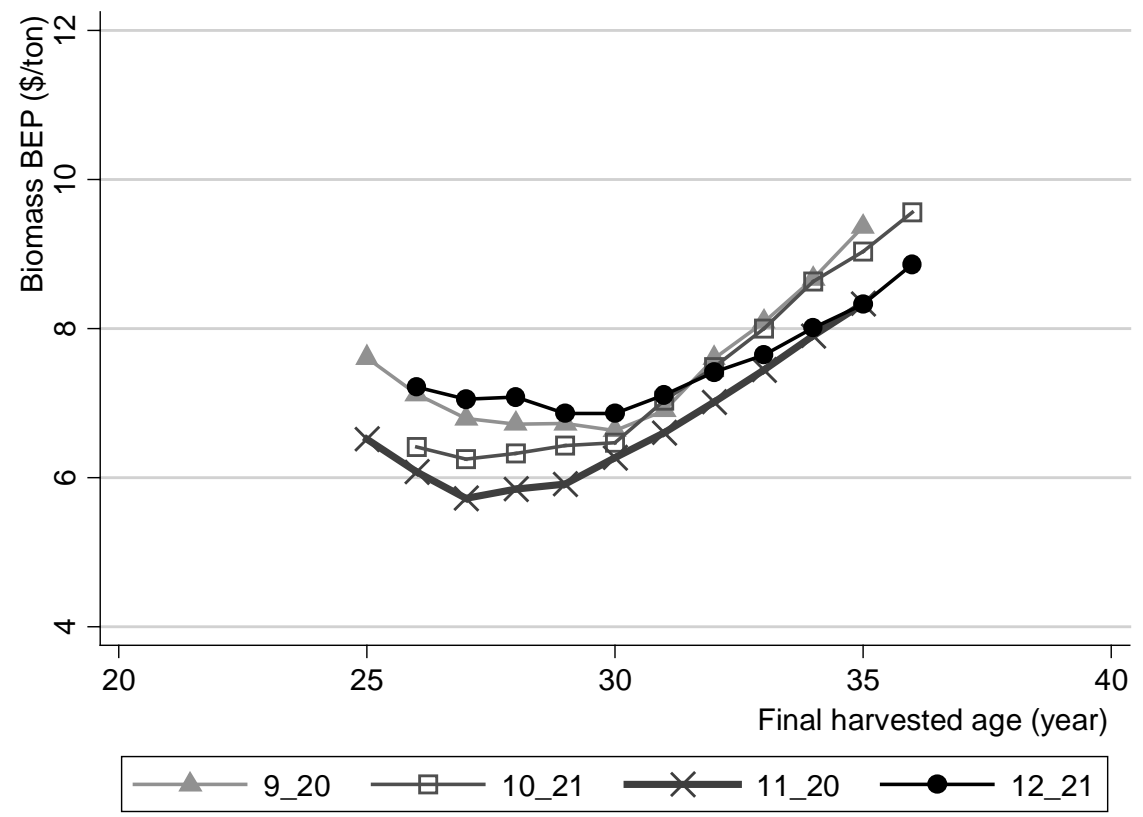

Figure 2. Breakeven price (BEP) curves and final rotation ages for biomass thinning ages from 9 to 12 years old on a Piedmont site at a $7 \%$ real discount rate. 


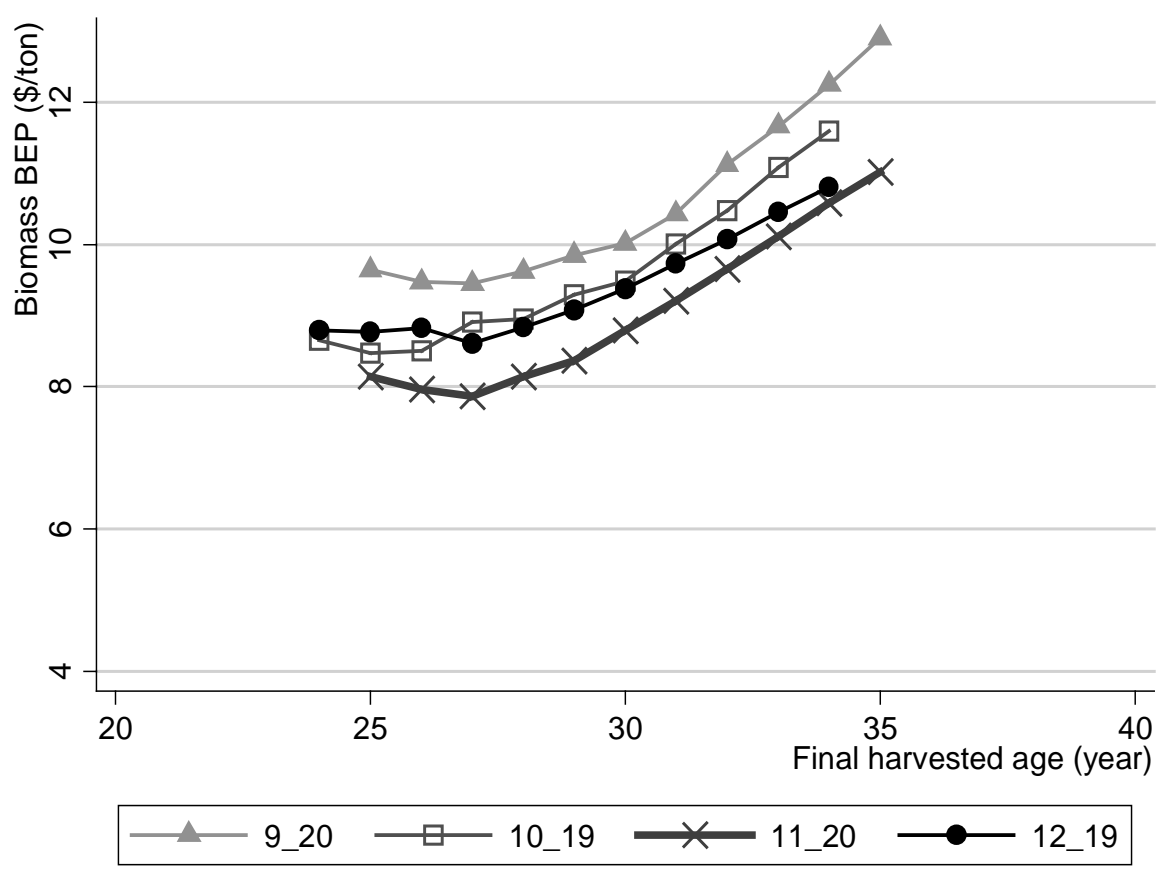

Figure 3. Breakeven price (BEP) curves and final rotation ages for biomass thinning ages from 9 to 12 years old on a Piedmont site at a $9 \%$ real discount rate.

found that biomass thinned at 11-years-old achieves the lowest BEP at all discount rates. At a $5 \%$ real discount rate the lowest BEP is from a regime that includes a pulpwood thinning at 24 years and a final harvest at 30 years. At higher discount rates, $7 \%$ and $9 \%$, the lowest BEP is associated with an earlier pulpwood thinning at 20 years and final harvests at 27 years (Figure 2, Figure 3). The rotation ages for the biomass thinning regime are shorter than the TMR at $5 \%$ and $7 \%$ discount rates but longer at a $9 \%$ discount rate.

The lowest BEP for a $5 \%$ discount rate is $\$ 4.75 /$ ton with a range of biomass lowest BEPs at each thinnable age $(9,10,11,12)$ from $\$ 4.75$ to $\$ 5.85 /$ ton. The lowest BEPs for the 7\% and 9\% discount rates are higher at $\$ 5.72$ and $\$ 7.87$ respectively. The ranges of lowest BEPS at each thinnable age are a little wider at $\$ 5.72-\$ 6.86 /$ ton and $\$ 7.87-\$ 9.45 /$ ton for the $7 \%$ and $9 \%$ discount rates.

\subsection{Biomass Breakeven Price on a Coastal Site}

Minimum BEPs on the Coastal Plain site are much higher than on the Piedmont site at all discount rates (Figures 4-6). Biomass thinning at age 6 years old is not at all financially competitive with later biomass thinning ages in terms of the required BEPs (30\% - 50\% higher). Thinning at 9 years old yields the lowest biomass BEP to match the TMR returns at all discount rates. The lowest BEPs are associated with the 9_16_26 management regime at a 5\% discount rate and a slightly shorter rotation regime (9_16_25) at discount rates of 7\%, and 9\%. However, the minimum BEPs for biomass in the Coastal Plain scenario are substantially higher at $\$ 16.01, \$ 15.05, \$ 14.75$ for real discount rates $5 \%, 7 \%$, $9 \%$ respectively, compared to the BEPs required in the Piedmont.

Rotation length is not affected much by changes in the discount rate under the 
Coastal Plain scenario. Under the Piedmont scenario increases in the discount rate lead to significantly shorter rotations ( 30 years at $5 \%$ vs. 25 years at $9 \%$ ). Under the Coastal Plain scenario the BEP curves become flatter with increases in the discount rate demonstrating that the BEP is relatively insensitive to slight adjustments in the rotation age, and vice-versa. For example, at a $9 \%$ discount rate, the BEPs for the 9_16 regime considering final harvest ages $21-25$ are in range of $\$ 14.75$ - $\$ 16.00 /$ ton while they are in a range from $\$ 16$ - $\$ 19 /$ ton at the $5 \%$

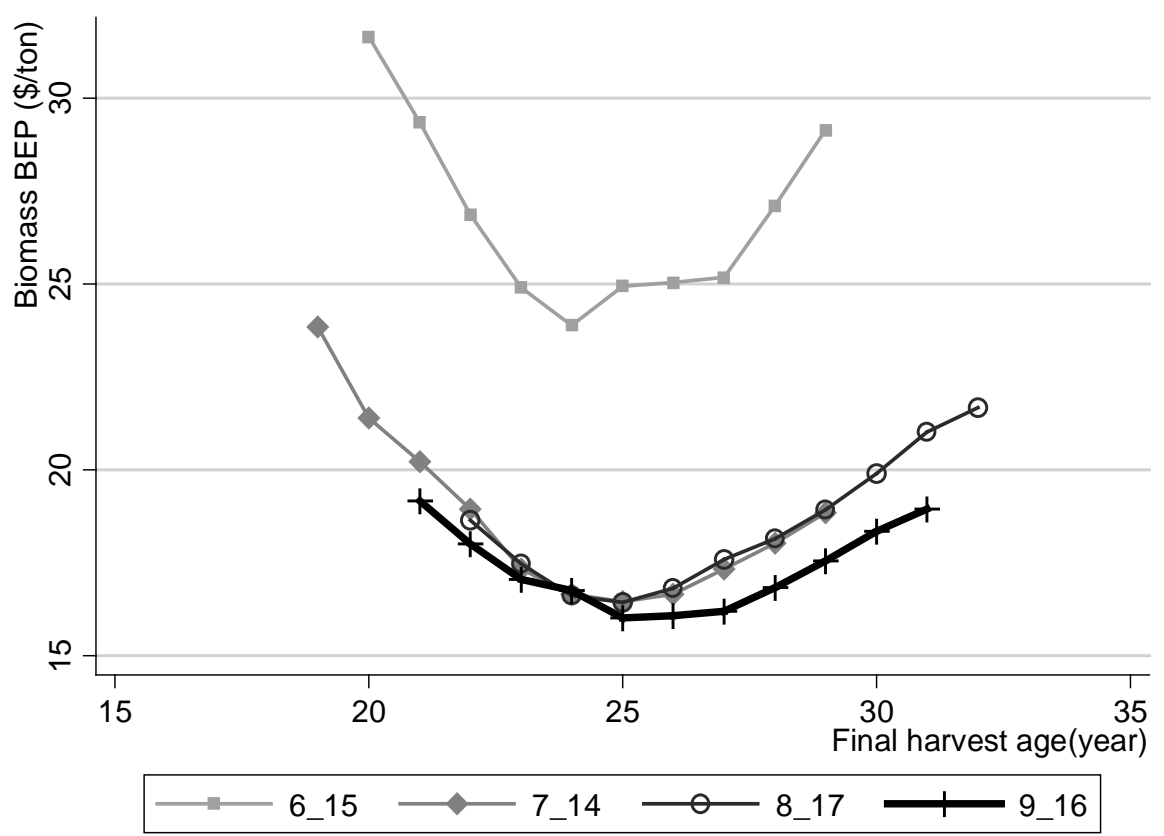

Figure 4. Breakeven price (BEP) curves and final rotation ages for biomass thinning ages from 6 to 9 years old on a Coastal Plain site at a $5 \%$ real discount rate.

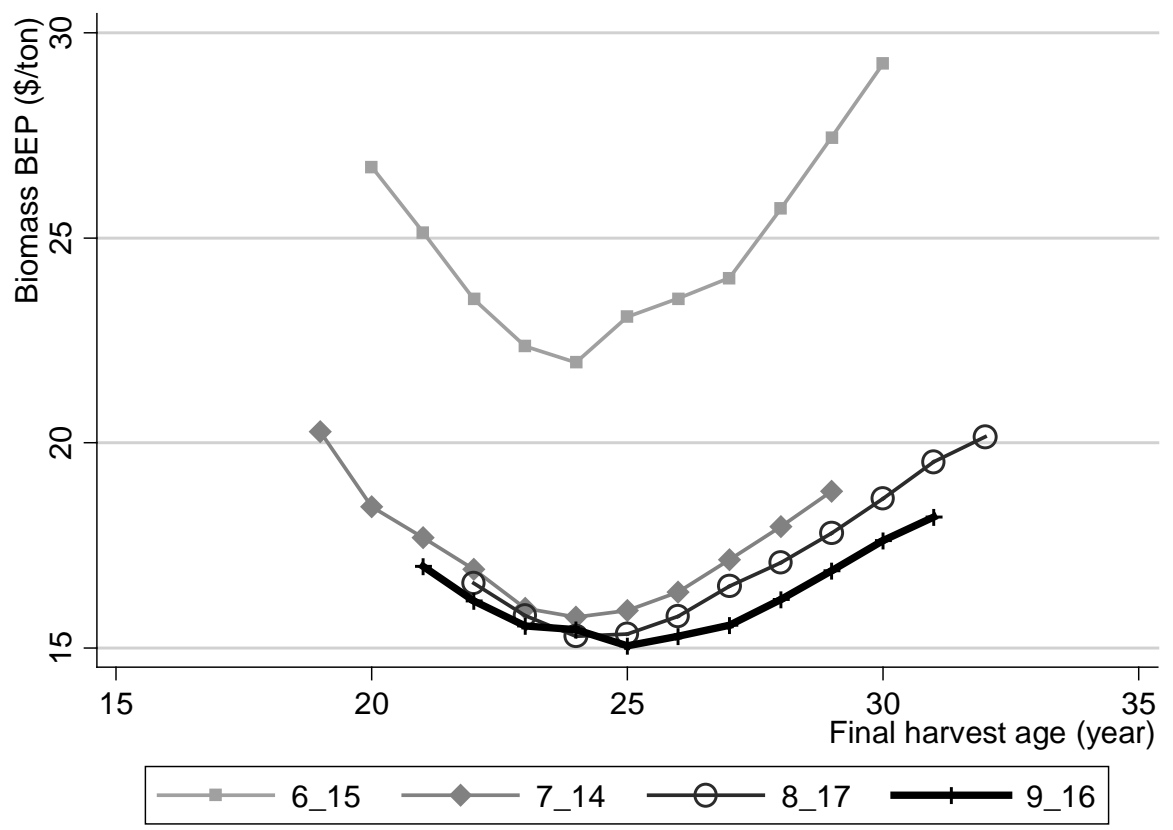

Figure 5. Breakeven price (BEP) curves and final rotation ages for biomass thinning ages from 6 to 9 years old on a Coastal Plain site at a $7 \%$ real discount rate. 


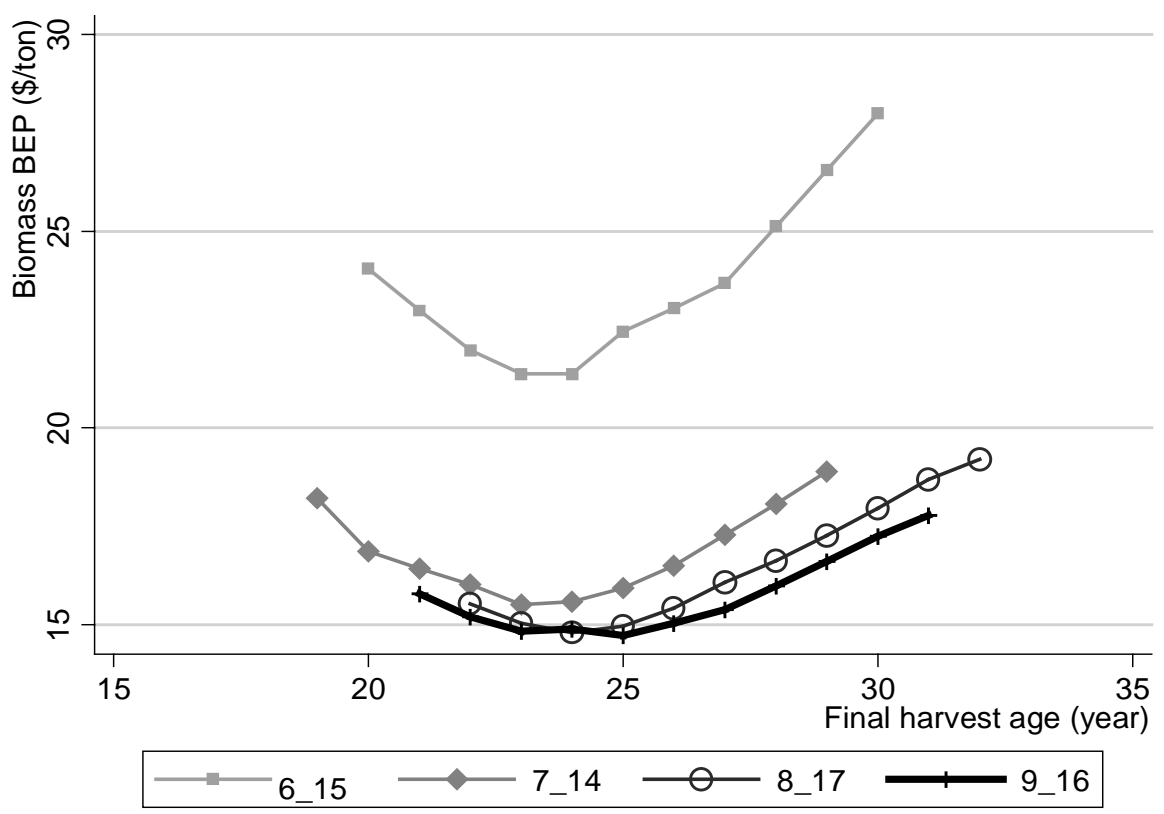

Figure 6. Breakeven price (BEP) curves and final rotation ages for biomass thinning ages from 6 to 9 years old on a Coastal Plain site at a $9 \%$ real discount rate.

discount rate. At high discount rates, discounted values of final harvested products in different years do not cause as much of a change in LEV; i.e., the marginal benefit of waiting one more year decreases with an increase in a discount rate.

\subsection{Sensitivity Analysis-Timber Price Increase}

It is important to underline the fact that the BEP mostly relies on current timber prices. As a result of the current economic downturn and its effect on housing, the 2012 sawtimber prices that were used in this study are historically low compared to those observed over the last 15 years in Alabama (an average real price/ton of \$48.74) (Timber Mart-South, 2012). To assess the impacts of an improving timber market in the future, Figure 7 and Figure 8 provide the results of a sensitivity analysis where the sawtimber price used in the traditional management scenarios is increased by $20 \%, 50 \%$ and $100 \%$ for the $7 \%$ discount rate under the lowest BEP regime examined for the Piedmont site.

It is interesting to notice how increases in timber prices lead to lower breakeven biomass prices. This may provide an enticement to some landowners to switch from a TMR to a biomass thinning strategy in this area. Our finding shows that biomass thinning provides the growth benefits of pre-commercial thinning, such as improvements in wood quality and accelerating tree growth yielding a higher proportion of timber in high value final products (Table 9). With the increases in timber prices, the minimum BEPs are lower and tend to extend the rotation in order to provide more timber production. At timber price increases of $20 \%$ and $50 \%$, minimum BEP decreases $13 \%$ and $30 \%$ from $\$ 5.71 /$ ton to $\$ 5.11$ and $\$ 4.20 /$ ton respectively, with the shift in rotation age from 27 years to 29 years rotation. When the timber price increases by $100 \%$, the minimum BEP decreases $70 \%$ to $\$ 1.87$ and the regime would be adjusted slightly 


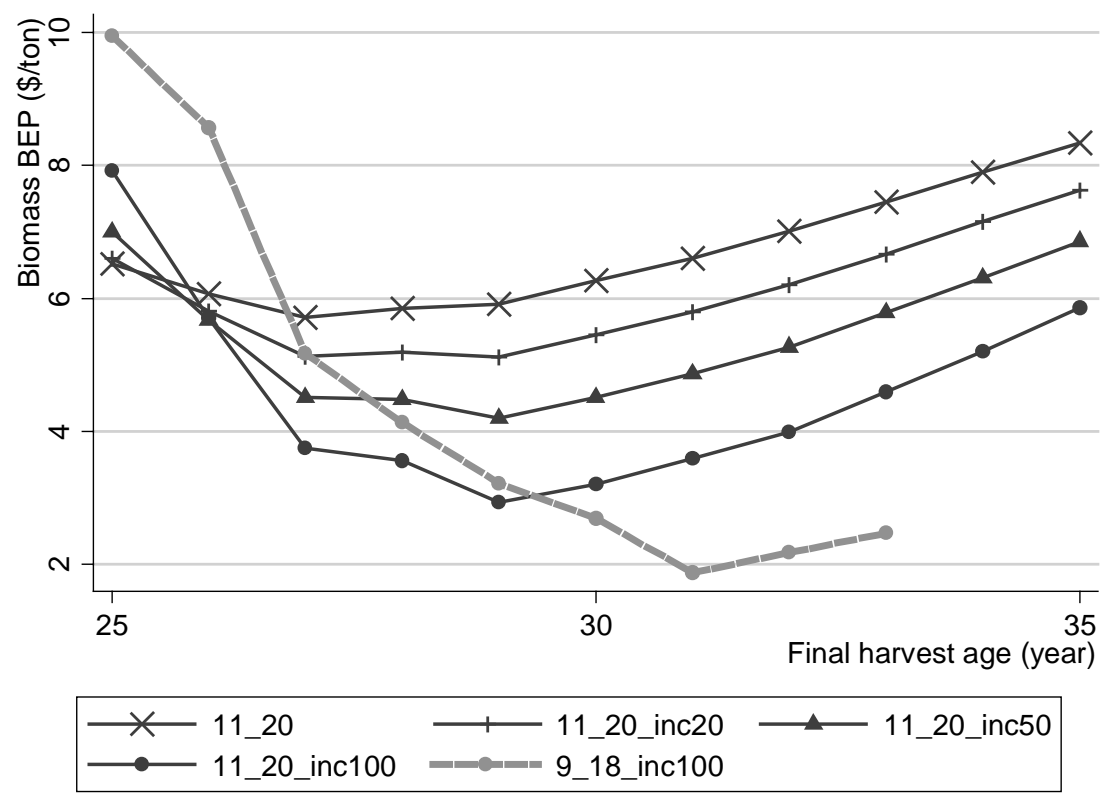

Figure 7. Comparison of BEPs with $0 \%, 20 \%, 50 \%$ and $100 \%$ timber price increases at a 7\% discount rate for the Piedmont site scenario regimes 11_20 and 9_18 (for 100\% timber price increase).

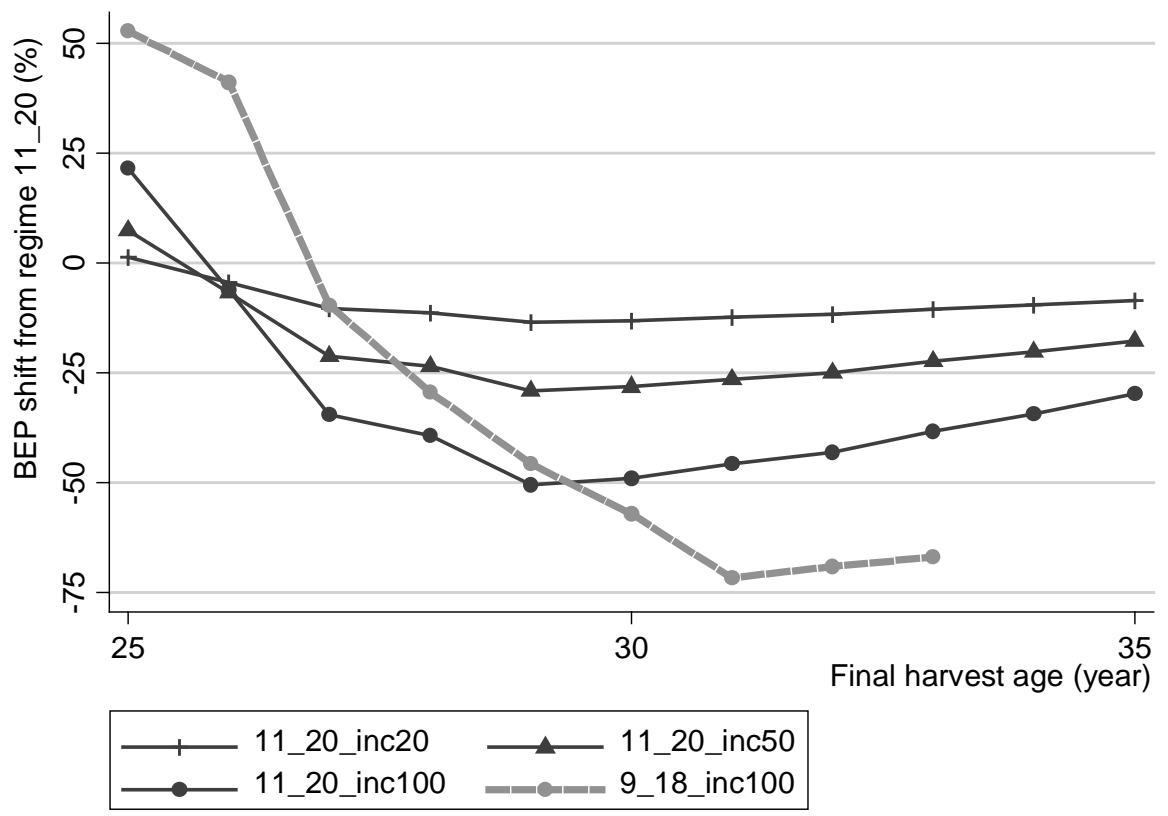

Figure 8. Percentage change in BEPs with $20 \%, 50 \%$, and $100 \%$ timber price increases at a $7 \%$ discount rate for the Piedmont site scenario.

by conducting the biomass thinning at an earlier time (age 9 vs. 11) and a later final harvest ( 31 years vs. 27 years) relative to the lowest BEP strategy given current prices.

\section{Discussion}

Given the ranges of real discount rates and biomass thinning regimes, this study found that the breakeven biomass price can be lower than pulpwood prices for a 
moderately productive $\left(\mathrm{SI}=65_{25}\right.$ ) site located in the Piedmont region of AL. These breakeven price results come from comparing the economic returns of a traditional management regime (TMR) with our designed biomass thinning regime (BTR) scenarios. The result shows that the assumed real discount rate is an important factor in the biomass plantation decision. Biomass BEPs increase with increases in discount rate. The BTR that achieved the lowest biomass BEP consists of an initial planting of 908 tpa, a third row and low thinning at 11 years old for 25 tons/ac of biomass, a second thinning for traditional timber products (mostly pulpwood) at 20 - 24 years depending on the real discount rate and a final harvest for traditional timber products (mostly sawtimber) at 27 - 30 years, also depending on the real discount rate. Minimum biomass BEPs range from $\$ 4.75$ - \$7.87 per ton given the discount rates applied (5\%, 7\%, and 9\%) and comparing to the current pulpwood price at $\$ 7.96$ per ton. This suggests that BTR is a reasonable regime and applicable to Piedmont sites for landowners who want to incorporate biomass products in their management plans. This alternative regime also captures the benefit of shortening the rotation at the lower discount rates examined (5\% and 7\%) compared to TMR. However, BTRs do not compare favorably to the TMR regime for the Coastal Plain scenario. Biomass BEPs from thinning regimes are higher than the current pulpwood price for this high site $\left(\mathrm{SI}=85_{25}\right)$ scenario across all discount rates.

Previous studies found that biomass thinnings are an attractive feedstock for alternative fuel markets and can be economically feasible (Rummer et al., 2003, Kocoloski et al., 2011). This study focuses on Alabama and provides consistent results regarding the economic viability of biomass thinning regimes which could play a crucial role in forest landowner decision making. Relative to the TMR option, including a biomass thinning in a management scenario can be financially attractive at biomass prices significantly below current pulpwood prices and at the same time, can lead to shorter rotations. Another advantage to landowners is the flexibility to either conduct a short rotation biomass harvest under a good biomass market and achieve an early economic return, or stay with the biomass thinning plan which depends on the biomass price at the time (Hinchee et al., 2009).

Thinning young stands has a long history as an important silvicultural treatment to shorten rotation length and improve wood quality characteristics such as; straightness, wood density, taper, ring counts and increase tree dimension and sawtimber proportion. Given recent changes in strength grading for southern pine lumber this could be an important marketing advantage in the future. Dense stands in the initiation stage have been suggested to promote high juvenile corewood stiffness due to cylindrical tree stem form (Roth et al., 2007). Once stands start the stem exclusion stage, thinning is important to control inter-tree competition, disease free conditions, and concentrate growth on retained trees. Thinning in young loblolly stands has been reported to increase bole diameter growth from higher physiological activities in lower crowns (Peterson et al., 1997). Table 9 shows a higher proportion of sawtimber from a biomass thinning 
Table 9. Green weight (tons) of pulpwood, chip \& saw and sawtimber and percentage of sawtimber at the final harvest age under the TMR compared with the BTR (regime 11_20) for the Piedmont site scenario.

\begin{tabular}{ccccccccc}
\hline \multicolumn{9}{c}{ TMR } \\
\hline $\begin{array}{c}\text { Age } \\
\text { (years) }\end{array}$ & $\begin{array}{c}\text { Pulp } \\
\text { (ton) }\end{array}$ & $\begin{array}{c}\text { Chip \& saw } \\
\text { (ton) }\end{array}$ & $\begin{array}{c}\text { Timber } \\
\text { (ton) }\end{array}$ & $\begin{array}{c}\text { Pct timber } \\
(\%)\end{array}$ & $\begin{array}{c}\text { Pulp } \\
\text { (ton) }\end{array}$ & $\begin{array}{c}\text { Chip \& saw } \\
\text { (ton) }\end{array}$ & $\begin{array}{c}\text { Timber } \\
\text { (ton) }\end{array}$ & $\begin{array}{c}\text { Pct timber } \\
(\%)\end{array}$ \\
\hline 25 & 26.6 & 53.2 & 9.0 & 10 & 17.4 & 23.1 & 25.9 & 39 \\
26 & 27.7 & 56.2 & 10.2 & 11 & 19.1 & 18.4 & 33.3 & 47 \\
27 & 30.4 & 51.5 & 17.7 & 18 & 21.0 & 13.2 & 41.1 & 55 \\
28 & 32.2 & 50.6 & 22.1 & 21 & 22.1 & 12.1 & 45.5 & 57 \\
29 & 34.6 & 45.7 & 29.9 & 27 & 23.4 & 8.9 & 51.6 & 62 \\
30 & 37.5 & 37.6 & 40.5 & 35 & 24.3 & 7.4 & 56.0 & 64 \\
31 & 39.3 & 34.8 & 46.5 & 39 & 25.1 & 6.7 & 60.2 & 65 \\
32 & 41.4 & 30.4 & 53.8 & 43 & 26.0 & 4.9 & 64.9 & 68 \\
33 & 42.9 & 29.1 & 58.6 & 45 & 26.5 & 4.2 & 69.1 & 69 \\
\hline
\end{tabular}

regime which was thinned twice (for biomass and later for pulpwood) compared with a traditional regime which was thinned once. This analysis is conducted based on timber prices in 2012 which was a recession market and not a good representation of historical price norms. It is reasonable and very likely that timber prices could increase in the future. According to the analysis, when timber prices increase, biomass thinning proves to be even more desirable, at least at low to moderate discount rates for stands in the Piedmont.

\section{Conclusion}

This feasibility analysis indicates that biomass thinning regimes are applicable for moderate site index pine lands in the Piedmont region of Alabama with current biomass stumpage prices that are lower than current pulpwood prices. The same is not true in the Coastal Plain where site index is generally much higher. Under favorable biomass and/or timber prices, forest landowners are encouraged to practice this proposed BTR due to the availability of early positive cash flows and the thinning effect of improving timber wood quality. Reliability of the BEP results depends on the representativeness of growth model simulations and assumptions of timber price and management regimes. Future research efforts should be focused on appropriate biomass harvesting methods and their economies of scale.

\section{Acknowledgements}

This work was partially funded by the Department of Energy under agreement 10-CO-11330132-088.

\section{References}

Barlow, R. J., \& Dubois, M. R. (2011). Cost and Cost Trends for Forestry Practice in the 
South. Forest Landowners, 70, 14-24.

Bower, D. R. (1965). Precommercial Thinnings Accelerate Diameter Growth of Loblolly Pine. Journal of Forestry, 63, 210.

Burkhart, H. E., Amateis, R. L., \& Westfall, D. R. F. (2008). Computer Program. PTAEDA4.0: Simulation of Individual Tree Growth, Stand Development and Economic Evaluation in Loblolly Pine Plantations. Blacksburg, VA: Virginia Tech University.

Cain, M. A., \& Shelton, M. G. (2003). Effects of Alternative Thinning Regimes and Prescribed Burning in Natural, Even-Aged Loblolly-Shortleaf Pine Stands: 25 Year Results. South. Journal of Applied Forestry, 27, 18-29.

Cregg, B. M., Dougherty, P. M., \& Hennessey, T. C. (1988). Growth and Wood Quality of Young Loblolly-Pine Trees in Relation to Stand Density and Climatic Factors. Canadian Journal of Forest Research, 18, 851-858. https://doi.org/10.1139/x88-131

Dickens, E. D., McElvany, B., Irwin, K. M., \& Wynne, T. L. (2005). Fertilization of Unthinned Loblolly Pine on an Intensively Prepared Cut-Over Site in Twiggs County, Georgia: Four Year Results (7 p.). Georgia Forest Productivity (Pub 001R-05).

Gorman, J. (2012). Institutional Timberland Investments: Asset Pricing and the Discount Rate (87 p.). PhD Dissertation, Auburn, AL: Auburn University.

Guo, Z. M., Grebner, D., Sun, C. Y., \& Grado, S. (2010). Evaluation of Loblolly Pine Management Regimes in Mississippi for Biomass Supplies: A Simulation Approach. South. Journal of Applied Forestry, 34, 65-71.

Hinchee, M., Rottmann, W., Mullinax, L., Zhang, C. S., Chang, S. J., Cunningham M. et al. (2009). Short-Rotation Woody Crops for Bioenergy and Biofuels Applications. In Vitro Cellular \& Developmental Biology-Plant, 45, 619-629.

https://doi.org/10.1007/s11627-009-9235-5

Kantavichai, R., Gallagher, T. V., \& Teeter, L. D. (2014). Assessing the Economic Feasibility of Short Rotation Loblolly Biomass Plantations. Forest Policy and Economics, 38, 126-131. https://doi.org/10.1016/j.forpol.2013.05.003

Kocoloski, M., Griffin, W. M., \& Matthews, H. S. (2011). Estimating National Costs, Benefits, and Potential for Cellulosic Ethanol Production from Forest Thinnings. Biomass and Bioenergy, 35, 2133-2142.

LeVan-Green, S. L., \& Livingston, J. (2001). Exploring the Uses for Small-Diameter Trees. Journal of Natural Products, 51, 10-21.

Munsell, J. F., \& Fox, T. R. (2010). An Analysis of the Feasibility for Increasing Woody Biomass Production from Pine Plantations in the Southern United States. Biomass and Bioenergy, 34, 1631-1642.

Paula, A. L., Bailey, C., Barlow, R. J., \& Morse, W. (2011). Landowner Willingness to Supply Timber for Biofuel: Results of an Alabama Survey of Family Forest Landowners. South. Journal of Applied Forestry, 35, 93-97.

Perlack, R. D., \& Stokes, B. J. (2011). US Billion-Ton Update: Biomass Supply for a Bioenergy and Bioproducts Industry (227 p). Oak Ridge, TN: Oak Ridge National Laboratory.

Peterson, J. A., Seiler, J. R., Nowak, J., Ginn, S. E., \& Kreh, R. E. (1997). Growth and Physiological Responses of Young Loblolly Pine Stands to Thinning. Forest Science, 43, 529-534.

Polagye, B. L., Hodgson, K. T., \& Malte, P. C. (2007). An Economic Analysis of BioEnergy Options Using Thinnings from Overstocked Forests. Biomass and Bioenergy, 31, 105-125.

Roth, B. E., Li, X., Huber, D. A., \& Peter, G. F. (2007). Effects of Management Intensity, Genetics and Planting Density on Wood Stiffness in a Plantation of Juvenile Loblolly 
Pine in the Southeastern USA. Forest Ecology and Management, 246, 155-162.

Rummer, B., Klepac, J., \& Thompson, J. (2012). Technology for Biomass Feedstock Production in Southern Forests and GHG Implications. In J. R. Butnor (Ed.), Proceedings of the 16th Biennial Southern Silvicultural Research Conference (pp. 278-282, SRS156). Asheville, NC: E-Gen. Tech. Rep.

Rummer, B., Prestemon, J., May, D., Miles, P., Vissage, J., McRoberts, R. et al. (2003). A Strategic Assessment of Forest Biomass and Fuel Reduction Treatments in Western States (p. 18). Washington DC: US Department of Agriculture, Forest Service.

South, D. B., Johnson, R., Hainds, M., \& Vander Schaaf, C. L. (2011). Realized Gains from Planting Pinus taeda in 6.1 Meter Rows in Alabama. The Open Forensic Science Journal, 4, 71-77.

Timber Mart-South (2012). Annual Report. Athens, GA: Warnell School of Forest Resources, University of Georgia.

Young, T., Wang, Y., Guess, F., Fly, M., Hodges, D., \& Poudyal, N. (2015). Understanding the Characteristics of Non-Industrial Private Forest Landowners Who Harvest Trees. Small-Scale Forestry, 14, 273-285. https://doi.org/10.1007/s11842-015-9287-9

Zhao, D. H., Kane, M., Borders, B., Subedi, S., \& Akers, M. (2012). Effects of Cultural Intensity and Planting Density on Stand-Level Aboveground Biomass Production and Allocation for 12-Year-Old Loblolly Pine Plantations in the Upper Coastal Plain and Piedmont of the Southeastern United States. Canadian Journal of Forest Research, 42, 111-122. https://doi.org/10.1139/x11-166

Submit or recommend next manuscript to SCIRP and we will provide best service for you:

Accepting pre-submission inquiries through Email, Facebook, LinkedIn, Twitter, etc. A wide selection of journals (inclusive of 9 subjects, more than 200 journals)

Providing 24-hour high-quality service

User-friendly online submission system

Fair and swift peer-review system

Efficient typesetting and proofreading procedure

Display of the result of downloads and visits, as well as the number of cited articles Maximum dissemination of your research work

Submit your manuscript at: http://papersubmission.scirp.org/

Or contact ojf@scirp.org 